\title{
Response of four woody species to salinity and water deficit in initial growth phase
}

\author{
Alan D. Lima ${ }^{1}$, Francisco M. S. Bezerra ${ }^{1}$, Antônia L. R. Neves ${ }^{1}$, \\ Carlos H. C. de Sousa' ${ }^{1}$, Claudivan F. de Lacerda ${ }^{1}$ \& Antônio M. E. Bezerra ${ }^{2}$ \\ ${ }^{1}$ Universidade Federal do Ceará/Departamento de Engenharia Agrícola/Programa de Pós-Graduação em Engenharia Agrícola. Fortaleza, CE. E-mail: \\ alandinizlima@yahoo.com.br (Corresponding author) - ORCID: 0000-0001-6939-4210; mardonesagronomia@gmail.com - ORCID: 0000-0002-8278- \\ 8182; leilaneves7@hotmail.com - ORCID: 0000-0002-2555-5390; sousaibiapina@yahoo.com.br - ORCID: 0000-0001-9462-4647; cfeitosa@ufc.br - ORCID: \\ 0000-0002-5324-8195 \\ ${ }^{2}$ Universidade Federal do Ceará/Departamento de Fitotecnia/Programa de Pós-Graduação em Fitotecnia. Fortaleza, CE. E-mail: esmeraldo@ufc.br - \\ ORCID: 0000-0003-0060-5803
}

\section{Key words:}

native plants

salt stress

water stress

\begin{abstract}
A B S T R A C T
The objective of this study was to evaluate the growth of forest species under conditions of salinity and water deficit. The experimental design was completely randomized in a triple factorial scheme with four forest species (Neem - Azadirachta indica A. Juss, 'Aroeira' Myracrodruon urundeuva Fr Allemão, 'Ipê' - Tabebuia impetiginosa (Mart. ex. DC.) Standl and 'Sabiá - Mimosa caesalpiniifolia Benth), two salinity levels (1.2 and $8.6 \mathrm{dS} \mathrm{m}^{-1}$ ) and two water regimes (with and without water restriction). Plant height, stem diameter, number of leaves, shoot dry matter, root dry matter and total dry matter were measured. For all the studied variables, there was statistical significance for the factors species (A) and salinity (B), individually. However, water deficit (Factor $\mathrm{C}$ ) and the interaction among factors (A x B x C) did not cause any statistical effect. The $50 \%$ reduction in water replacement for the four species studied was not enough to cause significant damage to plant growth, with a mean reduction in dry matter production lower than $10 \%$. It was observed that the tolerance index found varied according to the imposition of the stresses, being caused mainly by salinity. Based on shoot dry matter production, the species Neem behaved as moderately tolerant, while the other species were moderately sensitive to salinity. The applied water deficit was not enough to intensify the effects of the salt stress under the conditions of the present study.
\end{abstract}

Palavras-chave:

plantas nativas estresse salino estresse hídrico

\section{Resposta de quatro espécies lenhosas à salinidade e déficit hídrico em fase inicial de crescimento}

\section{R E S U M O}

Objetivou-se nessa pesquisa avaliar o crescimento de espécies florestais sob condições de salinidade e déficit hídrico. O delineamento experimental foi inteiramente casualizado, em esquema fatorial triplo, com quatro espécies florestais (Nim, Aroeira, Ipê e Sabiá), dois níveis de salinidade $\left(1,2\right.$ e $\left.8,6 \mathrm{dS} \mathrm{m}^{-1}\right)$ e dois regimes hídricos (com e sem restrição hídrica). Foram medidos a altura das plantas, diâmetro do caule, número de folhas, massa seca da parte aérea, massa seca das raízes e massa seca total. Verificou-se que em todas as variáveis estudadas houve significância estatística para os fatores espécies (A) e salinidade (B), isoladamente. Já o déficit hídrico (Fator $\mathrm{C}$ ) e a interação dos fatores A x B x C não causaram nenhuma inferência estatística. A redução de $50 \%$ da reposição de água para as mudas das quatro espécies estudadas não foi suficiente para provocar danos significativos ao crescimento das plantas, com redução média na produção de matéria seca inferior a $10 \%$. Com base na produção de matéria seca da parte aérea, verifica-se que a espécie Nim se comportou como moderadamente tolerante, enquanto as demais espécies se mostraram moderadamente sensíveis à salinidade. O déficit hídrico empregado não foi suficiente para intensificar os efeitos do estresse salino nas condições do presente estudo. 


\section{INTRODUCTION}

Forest resources involving the areas with tree species have undergone extensive exploitation and still suffer other types of damages, arising not only from anthropogenic causes, but also from biotic and abiotic factors, such as soil salinity and water deficit, common in semi-arid regions.

In semi-arid regions, high evapotranspiration rates and low rainfall levels contribute to the accumulation of soluble salts in the soil, and this process is intensified in areas with drainage problems. Under salinity conditions, plants exhibit symptoms such as necrosis and burns at leaf edges, usually caused by sodium and chlorine salts; however, the main response to the toxic and osmotic effects caused by salts is the reduction in plant growth (Taiz \& Zeiger, 2013).

The use of species with higher tolerance to salinity has been a strategy recommended in the recovery of soils degraded by the excess of salts and sodium (Qadir et al., 2007; Miranda et al., 2018). However, few studies with this focus have been conducted with tree species under Brazilian semi-arid conditions, and particularly with native plants of the Caatinga. Many of the species in this ecosystem have potential for multiple uses, but studies on their tolerance to salinity are still scarce (Silva et al., 2008; Bessa et al., 2017), notably under field conditions.

Another relevant issue is that salinity does not act in isolation under natural conditions, and the imposition of multiple stresses on plants is more rule than exception (Larcher, 2000; Mittler, 2006). Thus, plants growing in salt-affected soils may also suffer action of other abiotic stress factors, such as water deficit or excess. These factors acting together can intensify the negative effects on plants (Silva et al., 2017), hindering the process of revegetation of these areas, being particularly decisive in the establishment of seedlings under these conditions (Silva et al., 2016; Medeiros et al., 2018).

In this context, with the increasing need for recovery of areas degraded by salinization and solonization, there has been an increased interest in forest species adapted to the semi-arid region and with capacity for establishment under such soil conditions, associated with the water restriction that characterizes a significant part of the Northeast region of Brazil. Therefore, this study aimed to evaluate the initial growth of four forest species, three native to the Caatinga and one exotic, under conditions of salinity and water deficit.

\section{Material AND Methods}

The experiment was conducted at the Center of Education and Research in Urban Agriculture (NEPAU) of the Plant Science Department of the Federal University of Ceará - UFC, located in Fortaleza, CE, Brazil ( $3^{\circ} 44^{\prime}$ S; 38 33' W; 20 m), from April 11 to September 5, 2014.

To compose the treatments with levels of salts, a soil classified as Fluvic Neosol (EMBRAPA, 2006) was collected at different points in the Irrigated Perimeter of Morada Nova. The points were selected based on in-situ analysis of soil electrical conductivity in the $0-20 \mathrm{~cm}$ layer, using a Wet Jet sensor (Delta $\mathrm{T}$ - Devices, Cambridge, England). After collection, this soil was pounded to break up clods and sieved through a $5-\mathrm{mm}$ mesh, and electrical conductivity of the saturated soil (EC) was measured, resulting in two salinity treatments (1.2 and $\left.8.6 \mathrm{dS} \mathrm{m}^{-1}\right)$.

Four forest species were used in the experiment: three native to the Caatinga, 'Aroeira' (Myracrodruon urundeuva Fr Allemão), 'Sabiá' (Mimosa caesalpiniifolia Benth) and 'Ipê roxo' (Tabebuia impetiginosa (Mart. ex. DC.) Standl) and one exotic species, Neem (Azadirachta indica A. Juss). Species from the Caatinga were selected based on the previous knowledge on their responses to saline stress alone in the seedling stage (Bessa et al., 2017). It is necessary to evaluate their responses to multiple stress conditions and compare them with an exotic species, in this case Neem, which has aroused the interest of various producers due to its rusticity.

Seedlings were produced in greenhouse under $50 \%$ shading by sowing on polystyrene trays with 128 cells and substrate of sand + earthworm humus at 2:1 proportion, where they remained for 20 days and were daily irrigated by microsprinklers using well water with electrical conductivity of $0.7 \mathrm{dS} \mathrm{m}^{-1}$.

At 20 days after sowing, the seedlings were selected according to uniformity and transplanted to 8 - L pots containing a 5-cm-layer of crushed stone at the bottom and filled with soils with different levels of salinity. To reduce the impact of the direct contact between seedling root system and saline soil, the holes in each pot received an adequate volume of washed river sand (Bessa et al., 2017). The treatment with water restriction was only applied 20 days after transplanting (DAT). Plants remained in the pots until 120 DAT and were manually irrigated every day.

The experimental design was completely randomized, in a triple factorial scheme, $4 \times 2 \times 2$, relative to four forest species ('Aroeira,' 'Ipê', 'Sabiá' and Neem), two salinity levels (1.2 and $8.6 \mathrm{dS} \mathrm{m}^{-1}$ ) and two water regimes (with and without water restriction, WR and WoR, respectively). Four replicates were used, totaling 64 experimental units.

Water regime treatments were obtained by applying water depths equivalent to 100 and $50 \%$ in the treatments without restriction (WoR) and with restriction (WR), respectively, based on reference evapotranspiration determined by the Class A pan method. Plants were subjected to different treatments at $21 \mathrm{DAT}$ and remained under different water regimes until 120 DAT.

At the end of the experiment, plant height $(\mathrm{PH})$, stem diameter (SD), number of leaves (NL), shoot dry matter $(\mathrm{SDM})$, root dry matter (RDM) and total dry matter (TDM) were measured.

The results were subjected to analysis of variance by $\mathrm{F}$ test and means were compared by Tukey test at 0.05 probability level, using the program Assistat, beta version 7.6 (Silva \& Azevedo, 2016).

\section{Results AND Discussion}

The factors A (species) and B (salinity), individually, had significant effect on all variables studied ( $\mathrm{p}<0.01$ or $\mathrm{p}$ $<0.05)$. On the other hand, the factor water deficit $(C)$ and 
the interaction between factors $(\mathrm{A} \times \mathrm{B} \times \mathrm{C})$ did not cause any statistical difference $(\mathrm{p}>0.05)$. The interactions $\mathrm{A} \times \mathrm{B}$ and $\mathrm{B}$ $\mathrm{x} C$ had significant effect only on SDM $(\mathrm{p}<0.05)$, whereas the interaction A x C had significant effect on SD ( $p<0.05)$, SDM $(\mathrm{p}<0.05)$ and TDM $(\mathrm{p}<0.01)$.

In Figure 1A, it is possible to note the difference in plant height between Neem and the other species. On average, Neem was $54 \%$ superior, which caused it to be statistically different from the others. The species 'Aroeira', 'Ipê' and 'Sabiá' had heights of $33.75,33.25$ and $41.5 \mathrm{~cm}$, respectively. According to the statistical difference found between the soils without salinity (WoS) and with salinity (WS) regarding the mean height of the evaluated species (Figure 1B), PH was higher when plants were grown in soil without salinity.

The reduction of growth observed in the saline treatment act as an adaptive mechanism of the plant to salt stress, providing conditions for it to maintain its vital activities, even in limited manner. In addition, the development stage in which the stress occurs is also critical (Pimentel, 2004), because it can affect the vegetative and reproductive development of the plant.

Figure 2A shows the difference between treatments without water restriction (WoR) and with water restriction (WR) for stem diameter (SD) in the species Neem and 'Aroeira'. Such difference was not observed for the species 'Ipê' and 'Sabiá. For the mean SD of the analyzed species as a function of salinity (Figure 2B), the WoS condition led to SD of $5.94 \mathrm{~mm}$, higher than the value found for the WS condition, $4.69 \mathrm{~mm}$.

Part of the results in the present study can be explained by the comments of Sun et al. (2009) and Yao et al. (2010), who mentioned the possibility of difference in effect of salinity
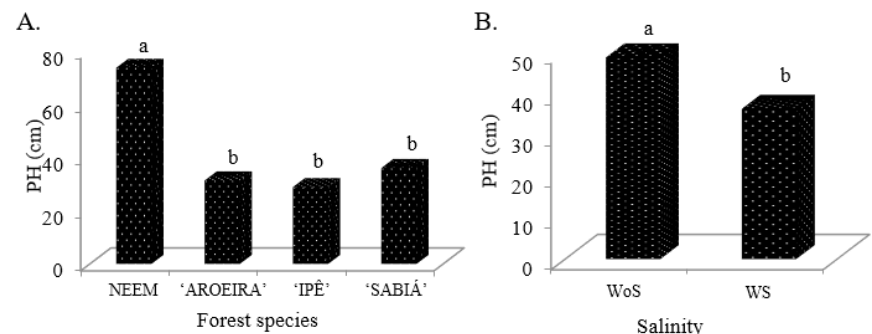

Means followed by the same letter do not differ statistically by Tukey test $(p>0.05)$, WoS - Without salinity, W - With salinity

Figure 1. Graphical representation of the test of means for plant height $(\mathrm{PH})$ for the evaluated species $(\mathrm{A})$ and salinity $(\mathrm{B})$
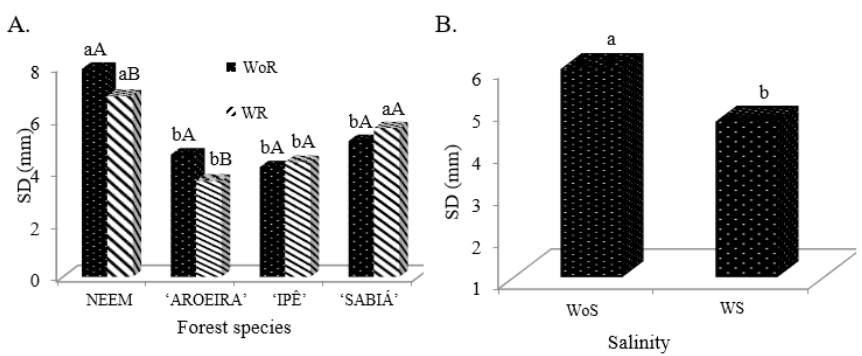

A - Bars with the same uppercase letters, for water regime, and by the same lowercase letters, for species, do not differ statistically by Tukey test $(p>0.05)$. B - Means followed by the same letter do not differ statistically by Tukey test ( $p>0.05)$; WoS - Without salinity, W - With salinity

Figure 2. Graphical representation of the test of means for stem diameter (SD) as a function of the interaction between species and water regime (A) and salinity (B) between plant species and between development stages of a same genotype. According to Nery et al. (2009), the reduction in stem diameter growth is more expressive than the growth in plant height.

Figure $3 \mathrm{~A}$ shows the graphical representation of the test of means for number of leaves (NL) as a function of the forest species. As occurred with plant height and stem diameter, Neem was also superior with respect to this variable. For NL, as a function of salinity in the analyzed species (Figure $3 \mathrm{~B}$ ), there was a $30 \%$ reduction in the treatment WS, compared with the WoS treatment, and this response was independent of the other factors studied.

For SDM as a function of the forest species (Figure 4A), the values were higher in Neem ( $8.79 \mathrm{~g}$ ), which differed from the other species. 'Aroeira, 'Ipê' and 'Sabiá' had values of 2.78, 2.11 and $3.18 \mathrm{~g}$, respectively, with no statistical difference from one another. For SDM as a function of the interaction between salinity and water regime (Figure 4B), the WoS condition caused higher values compared with the WS condition. The percentage reduction in SDM for the WoR and WR conditions between both salinity levels (WoS and WS) were respectively on the order of 53 and $56 \%$. Thus, it can be noted that the factor which most contributed to the reduction in SDM was soil salinity. Somehow, these reductions can be adaptive responses for plants to survive under stress, allowing them to have multiple resources to resist under adverse conditions.

Results similar to those observed in this study were found by Freire \& Rodrigues (2009), who studied the development of Leucaena leucocephala in saline and non-saline soils and observed that there was greater shoot and total dry matter accumulation in non-saline soil. However, the effect of soil
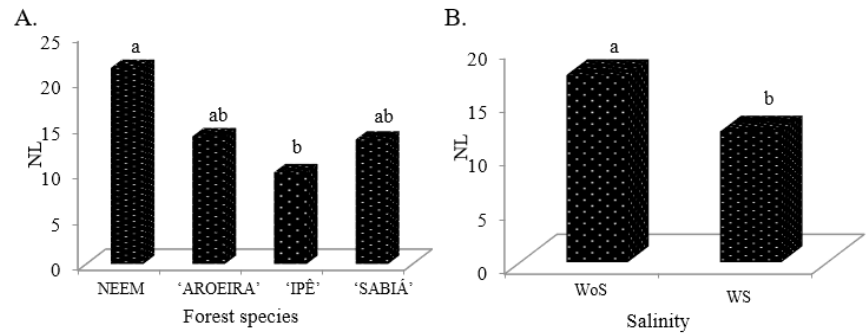

Means followed by the same letter do not differ statistically by Tukey test $(p>0.05)$; WoS - Without salinity, W - With salinity

Figure 3. Graphical representation of the test of means for number of leaves (NL) for the evaluated species $(\mathrm{A})$ and salinity (B)
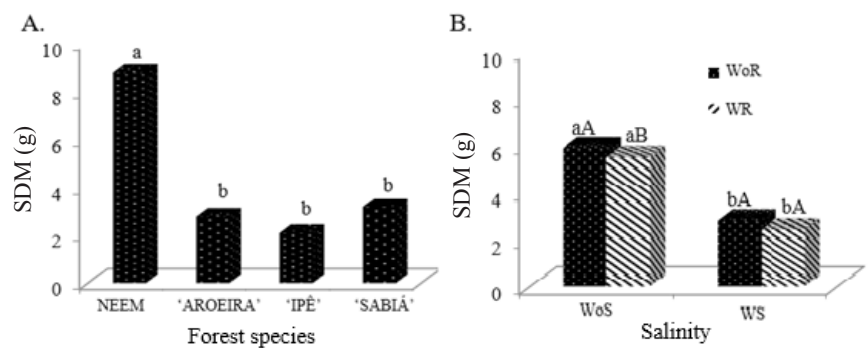

A - Means followed by the same letter do not differ statistically by Tukey $(p>0.05)$. B - Bars with the same lowercase letter, for salinity, and by the same uppercase letters, for water regime, do not differ statistically by Tukey $(p>0.05)$; WoS - Without salinity, W - With salinity Figure 4. Graphical representation of the test of means for shoot dry matter for the evaluated species (A) and interaction between salinity and water regime $(B)$ 
salinity was more pronounced on the shoots, causing a $60 \%$ reduction in the dry matter in comparison to plants grown in non-saline soils. Similarly, Gomes et al. (2011), in studies with Tabebuia aurea seedlings, observed that salinity significantly reduced shoot dry matter accumulation.

In the graphical representation of RDM as a function of the species (Figure 5A), the species Neem, 'Ipê' and 'Sabiá' were statistically different from one another, with absolute values of $6.10,4.44$ and $2.04 \mathrm{~g}$, respectively. For RDM as a function of salinity (Figure 5B), the trend was the same as that for SDM, since plants had lower values of SDM in the treatment with greater imposition of salt stress.

These responses can be justified possibly by the inhibition caused by the salt stress in vital processes, such as photosynthesis and synthesis of proteins (Parida \& Das, 2005). As a consequence, there may have been a reduction in leaf surface expansion, with considerable decrease in leaf area, fresh and dry biomass of leaves and roots (Chartzoulakis \& Klapaki, 2000), consequently leading to a significant decrease in plant growth rate (Rhoades et al., 1992). Silva et al. (2005) studying 'Favela' (Cnidosculus Phyllacanthus Pax \& K. Hoffm), observed that salt stress significantly inhibited the production of root dry matter (RDM) and shoot dry matter (SDM), particularly at the highest level of irrigation water salinity.

Corroborating the results found in this study, Silva et al. (2009) worked with the species 'Sabiá in a greenhouse and found that saline stress significantly inhibited the production of RDM and SDM, particularly at the highest level of irrigation water salinity ( $\mathrm{T} 6=6 \mathrm{dS} \mathrm{m} \mathrm{m}^{-1}$ ), and that these plants exhibited symptoms of early senescence and ionic toxicity (leaf burns), at 60 days of application of the treatments.

Figure 6 shows a graphical representation of the test of means for total dry matter (TDM) as a function of the interaction between species and water regime (A) and salinity (B). In Figure 6A, it is possible to see the superiority of the WoR treatment for Neem, and there were no effects of water restriction on the other species with respect to this variable. In general, the species 'Aroeira', 'Ipê' and 'Sabiá' did not show any statistical difference, either between species or water regimes. Conversely, in the graphical analysis of TDM as a function of salinity (Figure 6B), there was statistical difference between the two treatments, with values of 10.98 and $5.39 \mathrm{~g}$ for WoS and WS, respectively, which represents a reduction of $50 \%$ between treatments.

The large reduction caused by salt stress is partially due to the high concentrations of sodium salts, which negatively affect
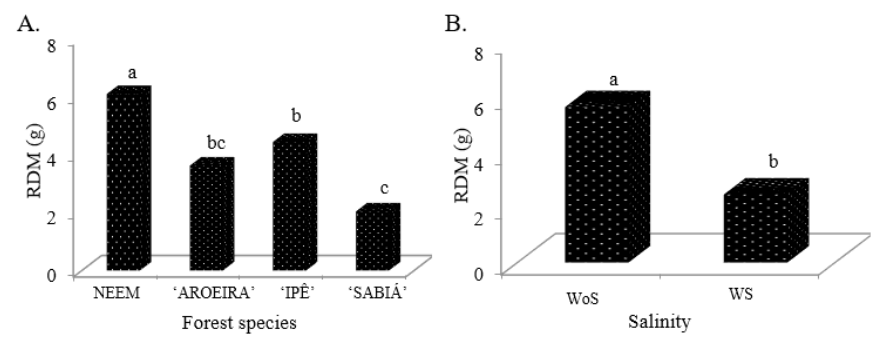

Means followed by the same letter do not differ significantly by Tukey test $(p>0.05)$; WoS - Without salinity, W - With salinity

Figure 5. Graphical representation of the test of means for root dry matter (RDM) for the evaluated species (A) and salinity (B)
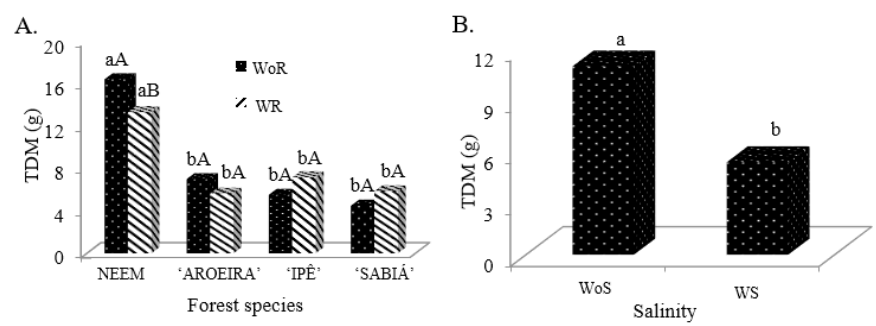

A - Bars with the same uppercase letters, for water regime, and by the same lowercase letters, for species, do not differ statistically by Tukey test $(p>0.05)$. B - Means followed by the same letter do not differ statistically by Tukey test ( $p>0.05)$; WoS - Without salinity, W - With salinity

Figure 6. Graphical representation of the test of means for total dry matter (TDM) as a function of the interaction between species and water regime (A) and salinity (B)

plant physiology by causing ionic, osmotic and nutritional interactions deleterious to plant cells (Hasegawa et al., 2000; Taiz \& Zeiger, 2013; Bessa et al., 2017). These responses, however, occur at different intensities according to the tolerance of plant species, with effects on biomass production (Chaves et al., 2009; Bessa et al., 2017).

The effects of salinity and water deficit on the total dry matter of the species studied in this work also reflect the effects observed on shoot dry matter and root dry matter. It can also be noted that, for all variables analyzed, the water regime with application of $50 \%$ water requirement was not sufficient to affect biomass production.

\section{Conclusions}

1. The $50 \%$ reduction in water replacement for seedlings of the four species studied was not enough to cause significant damages to their growth.

2. Based on shoot dry matter production, Neem behaved as moderately tolerant, whereas the other species were moderately sensitive to salinity.

3. The applied water deficit was not enough to intensify the effects of salt stress under the studied conditions.

\section{ACKnowledgments}

The authors thank the National Institute of Science and Technology in Salinity - INCTSal and National Council for Scientific and Technological Development - CNPq, for the financial support, and to the Coordination for the Improvement of Higher Education Personnel - CAPES for granting the scholarship to the first author.

\section{Literature Cited}

Bessa, M. C.; Lacerda, C. F. de; Amorim, A. V.; Bezerra, A. M. E.; Lima, A. D. Mechanisms of salt tolerance in seedlings of six woody native species of the Brazilian semi-arid. Revista Ciência Agronômica, v.48, p.157-165, 2017. https://doi.org/10.5935/1806-6690.20170018

Chartzoulakis, K.; Klapaki, G. Response of two greenhouse pepper hybrids to $\mathrm{NaCl}$ salinity during different growth stages. Scientia Horticulturae, v.86, p.247-260, 2000. https://doi.org/10.1016/ S0304-4238(00)00151-5 
Chaves, M. M.; Flexas, J.; Pinheiro, C. Photosynthesis under drought and salt stress: Regulation mechanisms from whole plant to cell. Annals of Botany, v.103, p.551-560, 2009. https://doi.org/10.1093/ aob/mcn 125

EMBRAPA - Empresa Brasileira de Pesquisa Agropecuária. Sistema brasileiro de classificação de solos. 2.ed. Rio de Janeiro: Embrapa Solos, 2006. 306p.

Freire, A. L. de O.; Rodrigues, T. de J. D. A salinidade do solo e seus reflexos no crescimento, nodulação e teores de $\mathrm{N}, \mathrm{K}$ e $\mathrm{Na}$ em leucena (Leucaena leucocephala (Lam.) De Vit.). Engenharia Ambiental, v.6, p.163-173, 2009.

Gomes, A. V.; Freire, A. L. de O.; Leite, M. H. A salinidade e seus reflexos no crescimento e acúmulo de solutos orgânicos em plantas de craibeira (Tabebuia aurea (Manso) Benth \& Hook). Revista Verde de Agroecologia e Desenvolvimento Sustentável, v.6, p.206-212, 2011.

Hasegawa, P. M.; Bressan, R. A.; Zhu, J. K.; Bohnert, H. J. Plant cellular and molecular responses to high salinity. Annual Review of Plant Physiology and Plant Molecular Biology, v.51, p.463-499, 2000. https://doi.org/10.1146/annurev.arplant.51.1.463

Larcher, W. Ecofisiologia vegetal. São Carlos: Rima, 2000. 533p.

Medeiros, W. J. F.; Oliveira, F. I. F.; Lacerda, C. F. de; Cavalcante, L. F.; Sousa, C. H. C.; Silva, A. R. A.; Ferreira, J. F. S. Isolated and combined effects of soil salinity and waterlogging in seedlings of green dwarf coconut. Semina: Ciências Agrárias, v.39, p.447457, 2018.

Miranda, M. F. A.; Freire, M. B. G. S.; Almeida, B. G.; Freire, A. G.; Freire, F. J.; Pessoa, L. G. M. Improvement of degraded physical attributes of a saline-sodic soil as influenced by phytoremediation and soil conditioners. Archives of Agronomy and Soil Science, v.64, p.1-15, 2018. https://doi.org/10.1080/03650340.2017.141 9195

Mittler, R. Abiotic stress, the field environment and stress combination. Trends in Plant Science, v.11, p.15-19, 2006. https:// doi.org/10.1016/j.tplants.2005.11.002

Nery, A. R.; Rodrigues, L. N.; Silva, M. B. R. da; Fernandes, P. D.; Chaves, L. H. G.; Dantas Neto, J.; Gheyi, H. R. Crescimento do pinhão manso irrigado com águas salinas em ambiente protegido. Revista Brasileira de Engenharia Agrícola e Ambiental, v.13, p.551558, 2009. https://doi.org/10.1590/S1415-43662009000500007

Parida, A. K.; Das, A. B. Salt tolerance and salinity effects on plants: A review. Ecotoxicologyand Environmental Safety, v.60, p.324-349, 2005. https://doi.org/10.1016/j.ecoenv.2004.06.010

Pimentel, C. A relação da planta com a água. Seropédica: UFRural, 2004. 192p.
Qadir, M.; Oster, J. D.; Schubert, S.; Noble, A. D.; Sahrawat, K. L. Phytoremediation of sodic and saline-sodic soils. Advances in Agronomy, v.96, p.197-247, 2007. https://doi.org/10.1016/S00652113(07)96006-X

Rhoades, J. D.; Kndiah, A.; Mashali, A. M. The use of saline waters for crop production. Rome: FAO, 1992. 40p. Irrigation and Drainage, Paper 48

Silva, A. R. A.; Bezerra, F. M. L.; Lacerda, C. F. de; Lima, R. M. M.; Araujo, M. E. B.; Sousa, C. H. C. Establishment of young dwarf green coconut plants in soil affected by salts and under water deficit. Revista Brasileira de Fruticultura, v.38, p.1-12, 2016. https://doi.org/10.1590/0100-29452016206

Silva, A. R. A.; Bezerra, F. M. L.; Lacerda, C. F. de; Sousa, C. H. C.; Bezerra, M. A. Physiological responses of dwarf coconut plants under water deficit in salt-affected soils. Revista Caatinga, v.30, p.447-457, 2017. https://doi.org/10.1590/1983-21252017v30n220rc

Silva, E. C.; Nogueira, R. J. M. C.; Araújo, F. P.; Melo, F. N.; Azevedo Neto, A. D. Physiological responses to salt stress in young umbu plants. Environmental and Experimental Botany, v.63, p.147-157, 2008. https://doi.org/10.1016/j.envexpbot.2007.11.010

Silva, F. de A. S. e; Azevedo, C. A. V. de. The assistat software version 7.7 and its use in the analysis of experimental data. African Journal of Agricultural Research, v.11, p.3733-3740, 2016. https://doi. org/10.5897/AJAR2016.11522

Silva, M. B. R. da; Batista, R. C.; Lima, V. L. A. de; Barbosa, E. M.; Barbosa, M. de F. N. Crescimento de plantas jovens da espécie florestal favela (Cnidosculus phyllacanthus Pax \& K. Hoffm) em diferentes níveis de salinidade da água. Revista de Biologia e Ciências da Terra, v.5, p.1-13, 2005.

Silva, M. B. R. da; Viegas, A. R.; Dantas Neto, J.; Farias, S. A. R. Estresse salino em plantas da espécie florestal Sabiá. Caminhos de Geografia, v.10, p.120-127, 2009.

Sun, J.; Dai, S.; Wang, R.; Chen, S.; Zhou, X.; Shen, X.; Zheng, X.; Zhang, Z.; Song, J.; Xu, Y. Calcium mediates root $\mathrm{K}^{+} / \mathrm{Na}^{+}$ homeostasis in poplar species differing in salt tolerance. Tree Physiology, v.29, p.1175-1186, 2009. https://doi.org/10.1093/ treephys/tpp048

Taiz, L.; Zeiger, E. Fisiologia vegetal. 5.ed. Porto Alegre: Artmed, 2013. 918p.

Yao, X.; Horie, T.; Xue, S.; Leung, H. Y.; Katsuhara, M.; Brodsky, D. E.; Schroeder, J. I. Differential sodium and potassium transport selectivities of the rice OsHKT2;1 and OsHKT2;2 transporters in plant cells. Plant Physiology, v.1, p.341-355, 2010. https://doi. org/10.1104/pp.109.145722 